http://dx.doi.org/10.11646/phytotaxa.118.2.3

\title{
The fern genus Dryopteris (Dryopteridaceae) in Ascension and Saint Helena islands, Atlantic Ocean
}

\author{
JACOBUS P. ROUX ${ }^{\dagger 1}$
}

South African National Biodiversity Institute, Compton Herbarium, Private Bag X7, Claremont 7735, Cape Town, South Africa I H.G.W.J. Schweickerdt Herbarium, Department of Plant Science, University of Pretoria, Pretoria 0002, South Africa.

\begin{abstract}
The fern genus Dryopteris (Dryopteridaceae) in the isolated Atlantic Ocean islands, Ascension and St Helena is reviewed. Three species are known from these islands. Dryopteris ascensionis is endemic to and the only Dryopteris species known from Ascension Island. This species now appears to be extinct since has not been recorded since 1975, and was not found during repeated searches in the 1990s. Two Dryopteris species, D. cognata and D. napoleonis, are endemic to St. Helena and are rare on that island. Dryopteris napoleonis is lectotypified.
\end{abstract}

Key words: Ascension Island, endemics, oceanic islands, St Helena, U.K. Overseas Territories

\section{Introduction}

Dryopteris Adanson (1763: 551) is a genus of about 225 species (Kramer et al. 1990: 110) in the strict sense, but is recently enlarged by Zhang (2012) to include several small mostly Asian genera, increasing the total to ca 350 species. It is one of the larger genera in Dryopteridaceae (Christenhusz et al. 2011) and has a nearly worldwide distribution. Dryopteris is less common in the southern hemisphere and nearly absent from Australia and New Zealand. The chief centre of diversity for the genus is the Sino-Himalayan region and south-western China, with minor centres of divergence in south-eastern and eastern Asia, Oceania, Africa, Europe and the Americas (Roux 2012).

Both Ascension Island and St Helena are oceanic islands positioned along the mid-Atlantic Ocean ridge and are of volcanic origin. Ascension is about 1 million years old compared to St Helena which formed about 14 million years ago (Ashmole \& Ashmole 2000).

Ascension Island $\left(7^{\circ} 57^{\prime} \mathrm{S}, 14^{\circ} 22^{\prime} \mathrm{W}\right)$ is situated about $1,500 \mathrm{~km}$ from the coast of West Africa and approximately $1,127 \mathrm{~km}$ north of St Helena. The island covers an area of about $88 \mathrm{~km}^{2}$ with the highest point, The Peak on Green Mountain being $859 \mathrm{~m}$ above sea level. On this island the day temperature at sea-level ranges between $27^{\circ} \mathrm{C}$ in September to $30^{\circ} \mathrm{C}$ in January. Green Mountain receives about $680 \mathrm{~mm}$ of rain annually and often accumulates cloud and mist making it one of the only sources of water as it seeps through the rocks. The lowlands receive as little as $130 \mathrm{~mm}$ of rain per annum and most of it occurs in the form of torrential downpours between March and May. For most of the year the lowlands are arid and desert-like.

The vegetation of Ascension Island has been significantly modified, mainly through the introduction of alien plants and animals. Currently more than 300 non-native plants species occur on the island compared to the 25 native vascular plant species that originally occurred there. Of the native species 12 were endemic to

1. This paper was published posthumously. Dr Roux unexpectedly passed away in a traffic accident on 12 May 2013. We decided to publish the manuscript, submitted on 4 April 2013, taking the positive reviewers comments into account. The plates were based on the preliminary versions sent to us for review purpose. 